\title{
Increased risk of lung cancer in individuals with a family history of the disease: A pooled analysis from the International Lung Cancer Consortium
}

\author{
Michele L. Coté ${ }^{1,{ }^{*},}$ Mei Liu ${ }^{2,}$, , Stefano Bonassi ${ }^{3}$, Monica Neri $^{3}$, Ann G. Schwartz ${ }^{1}$, David C. \\ Christiani $^{4}$, Margaret R. Spitz ${ }^{2}$, Joshua E. Muscat ${ }^{5}$, Gad Rennert ${ }^{6}$, Katja K. Aben ${ }^{7}$, Angeline \\ S. Andrew ${ }^{8}$, Vladimir Bencko ${ }^{9}$, Heike Bickeböller ${ }^{10}$, Paolo Boffetta ${ }^{11}$, Paul Brennan ${ }^{12}$, \\ Hermann Brenner ${ }^{13}$, Eric J. Duell ${ }^{14}$, Eleonora Fabianova ${ }^{15}$, John K. Field ${ }^{16}$, Lenka \\ Foretova $^{17}$, Søren Friis ${ }^{18}$, Curtis C. Harris ${ }^{19}$, Ivana Holcatova ${ }^{9}$, Yun-Chul Hong ${ }^{20}$, Dolores \\ Isla ${ }^{21}$, Vladimir Janout ${ }^{22}$, Lambertus A. Kiemeney ${ }^{23}$, Chikako Kiyohara ${ }^{24}$, Qing Lan ${ }^{25}$, \\ Philip Lazarus $^{26}$, Jolanta Lissowska ${ }^{27}$, Loic Le Marchand ${ }^{28}$, Dana Mates ${ }^{29}$, Keitaro \\ Matsuo $^{30}$, Jose I. Mayordomo ${ }^{21}$, John R. McLaughlin ${ }^{31}$, Hal Morgenstern ${ }^{32}$, Heiko \\ Müeller $^{13}$, Irene Orlow ${ }^{33}$, Bernard J. Park ${ }^{34}$, Mila Pinchev ${ }^{6}$, Olaide Y. Raji ${ }^{16}$, Hedy S. \\ Rennert $^{6}$, Peter Rudnai ${ }^{35}$, Adeline Seow ${ }^{36}$, Isabelle Stucker ${ }^{37}$, Neonila Szeszenia- \\ Dabrowska $^{38}$, M. Dawn Teare ${ }^{39}$, Anne Tjønnelan ${ }^{18}$, Donatella Ugolini ${ }^{40}$, Henricus F.M. van \\ der Heijden ${ }^{23}$, Erich Wichmann ${ }^{41,46}$, John K. Wiencke ${ }^{42}$, Penella J. Woll ${ }^{37}$, Ping Yang ${ }^{43}$, \\ David Zaridze ${ }^{44}$, Zuo-Feng Zhang ${ }^{45}$, Carol J. Etzel ${ }^{2,{ }^{* *}}$, and Rayjean J. Hung ${ }^{31,{ }^{* \star}}$
}

\begin{abstract}
${ }^{1}$ Wayne State University School of Medicine and the Karmanos Cancer Institute, Michigan, USA ${ }^{2}$ M.D. Anderson Cancer Center, Department of Epidemiology, Texas, USA ${ }^{3} \mathrm{Clinical}$ and Molecular Epidemiology IRCCS San Raffaele Pisana, Italy ${ }^{4}$ Harvard University School of Public Health, Massachusetts, USA ${ }^{5}$ Penn State University College of Medicine Division of Public Health Sciences, Pennsylvania, USA ${ }^{6} \mathrm{CHS}$ National Cancer Control Center and Department of Community Medicine and Epidemiology, Carmel Medical Center and Bruce Rappaport Faculty of Medicine, Technion - Israel Institute of Technology, Haifa Israel ${ }^{7}$ Comprehensive Cancer Center The Netherlands, Nijmegen, The Netherlands ${ }^{8}$ Norris Cotton Cancer Center, Department of Community \& Family Medicine, Dartmouth Medical School, Lebanon, NH, USA ${ }^{9}$ Institute of Hygiene and Epidemiology, Charles University, Prague, Czech Republic ${ }^{10}$ University of Göttingen, Medical School, Department of Genetic Epidemiology, Germany ${ }^{11}$ Mount Sinai School of Medicine, New York, USA ${ }^{12}$ International Agency for Research on Cancer (IARC), Lyon, France ${ }^{13}$ German Cancer Research Center, Division of Clinical Epidemiology and Aging Research, Germany ${ }^{14}$ Unit of Nutrition, Environment and Cancer, Catalan Institute of Oncology (ICO-IDIBELL), Barcelona, Spain ${ }^{15}$ Department of Occupational Health, Specialized State Health Institute, Slovakia ${ }^{16}$ The University of Liverpool Cancer Research Centre Roy Castle Lung Cancer Research Programme, UK ${ }^{17}$ Masaryk Memorial Cancer Institute, Czech Republic ${ }^{18}$ Danish Cancer Society, Institute of Cancer Epidemiology, Denmark ${ }^{19}$ National Cancer Institute,
\end{abstract}

\footnotetext{
(C) 2012 Elsevier Ltd. All rights reserved.

Corresponding Author: Michele L. Cote, PhD cotem@karmanos.org (313) 578-4204 4100 John R. Mailstop MM04EP Detroit, MI 48201 USA.

these authors contributed equally to this work

these authors contributed equally to this work

Publisher's Disclaimer: This is a PDF file of an unedited manuscript that has been accepted for publication. As a service to our customers we are providing this early version of the manuscript. The manuscript will undergo copyediting, typesetting, and review of the resulting proof before it is published in its final citable form. Please note that during the production process errors may be discovered which could affect the content, and all legal disclaimers that apply to the journal pertain. 
Molecular Genetics and Carcinogenesis Section, Maryland, USA ${ }^{20}$ Seoul National University, Korea ${ }^{21}$ University of Zaragoza, Division of Medical Oncology, Spain ${ }^{22}$ Department of Preventive Medicine, Palacky University of Medicine, Czech Republic ${ }^{23}$ Department of Epidemiology, Biostatistics and HTA and Department of Urology, Radboud University, Nijmegen Medical Centre, The Netherlands ${ }^{24}$ Kyushu University Department of Basic Medicine, Japan ${ }^{25}$ National Cancer Institute, Division of Cancer Epidemiology and Genetics, USA ${ }^{26}$ Penn State University, Penn State Cancer Institute, Pennsylvania, USA ${ }^{27}$ Department of Cancer Epidemiology and Prevention, Cancer Center and Maria Sklodowska-Curie Institute of Oncology, Warsaw, Poland ${ }^{28}$ University of Hawaii Cancer Center, Hawaii, USA ${ }^{29}$ Occupational Health Department, Institute of Public Health, Bucharest, Romania ${ }^{30}$ Aichi Cancer Center Research Institute, Japan ${ }^{31}$ Samuel Lunenfeld Research Institute, Ontario, Canada ${ }^{32}$ University of Michigan School of Public Health, Ann Arbor, MI, USA ${ }^{33}$ Memorial Sloan-Kettering Cancer, New York, USA ${ }^{34}$ Hackensack University Medical Center, New Jersey, USA ${ }^{35}$ National Institute of Environmental Health, Fodor Jozsef national Center for Public Health, Budapest, Hungary ${ }^{36}$ National University of Singapore, Yong Loo Lin School of Medicine, Singapore ${ }^{37}$ INSERM U170, Department of Environmental Epidemiology, France ${ }^{38}$ The Nofer Institute of Occupational Medicine, Poland ${ }^{39}$ University of Sheffield, Sheffield, UK ${ }^{40}$ Dipartimento di Oncologia, Biolgia e Genetica, University of Genoa and Unit of Epidemiology and Biostatistics and Clinical Trials, National Cancer Research Institute, Italy ${ }^{41}$ German Research Center for Environmental Health, Institute of Epidemiology, Helmholtz Center, Munich, Germany ${ }^{42}$ University of California, San Francisco, Department of Epidemiology and Biostatistics, California, USA ${ }^{43}$ Mayo Clinic, Division of Epidemiology, Minnesota, USA ${ }^{44}$ Institute of Carcinogenesis, N.N.Blokhin Cancer Research Centre, Moscow, Russia ${ }^{45}$ University of California, Los Angeles, School of Public Health Department of Epidemiology, California, USA ${ }^{46}$ IBE, Ludwig Maximilians University Munich

\section{Abstract}

Background and Methods-Familial aggregation of lung cancer exists after accounting for cigarette smoking. However, the extent to which family history affects risk by smoking status, histology, relative type and ethnicity is not well described. This pooled analysis included 24 casecontrol studies in the International Lung Cancer Consortium. Each study collected age of onset/ interview, gender, race/ethnicity, cigarette smoking, histology and first-degree family history of lung cancer. Data from 24,380 lung cancer cases and 23,305 healthy controls were analyzed. Unconditional logistic regression models and generalized estimating equations were used to estimate odds ratios and $95 \%$ confidence intervals.

Results-Individuals with a first-degree relative with lung cancer had a 1.51-fold increase in risk of lung cancer, after adjustment for smoking and other potential confounders(95\% CI: 1.39, 1.63). The association was strongest for those with a family history in a sibling, after adjustment $(\mathrm{OR}=1.82,95 \%$ CI: 1.62, 2.05). No modifying effect by histologic type was found. Never smokers showed a lower association with positive familial history of lung cancer (OR=1.25, 95\% CI: 1.03 , 1.52), slightly stronger for those with an affected sibling (OR=1.44, 95\% CI: 1.07, 1.93), after adjustment.

Conclusions-The increased risk among never smokers and similar magnitudes of the effect of family history on lung cancer risk across histological types suggests familial aggregation of lung cancer is independent of those associated with cigarette smoking. While the role of genetic variation in the etiology of lung cancer remains to be fully characterized, family history assessment is immediately available and those with a positive history represent a higher risk group. 


\section{Introduction}

Lung cancer is the leading cause of cancer-related deaths worldwide (1). Current and former smokers are at greatest risk, but lung cancer does occur among nonsmokers, with varying rates across countries (2). The association between cigarette smoking and increased risk of lung cancer is now undisputed. Despite this, less than $20 \%$ of smokers develop lung cancer, suggesting that the effect of tobacco smoke exposure is modified by other variables, including individual susceptibility (3). The search for a gene or genes associated with susceptibility is still nascent. Genome wide association studies have independently reported chromosomal region 15q24-25.1, which contains nicotinic acetylcholine receptor sub-unit genes, to be associated with increased risk of lung cancer in ever smokers (4-6). These findings have been replicated among individuals with a family history of lung cancer, and the relative risk of lung cancer associated with markers in this region are much higher for familial cases compared to the relative risk observed among sporadic cases (7). Linkage analysis in families with aggregation of lung cancer also described a region on chromosome 6q23-25 associated with risk of lung cancer (8). The clinical significance of these findings is still unclear. In the meantime, lung cancer risk models using epidemiologic data have been developed, and the most parsimonious models for both ever and never smokers include a family history of cancer variable (9).

Developing risk models for lung cancer are vital, given the report from the National Lung Screening Trial (NLST), which suggests that low-dose helical computed tomography (CT) scans may cut deaths from lung cancer by $20 \%$ (10). It should be noted these findings were among individuals 55-74 years of age, with a smoking history of 30+ pack years, and should not be extended to other populations (11). A crucial component to a successful screening program is defining a population at high risk. Until screening protocols have been developed, the main recommendations to reduce risk of lung cancer remain smoking avoidance, cessation, and limiting exposure to known carcinogens (e.g. radon, environmental tobacco smoke)(12).

Relatives of individuals with lung cancer may be at higher risk of lung cancer than the general population. Various smaller studies have provided evidence that familial aggregation of lung cancer exists after adjusting for the aggregation of cigarette smoking and type of family relatedness $(13,14)$. In this study, we performed a pooled analysis of data contributed to the International Lung Cancer Consortium, in order to describe in greater detail familial aggregation of lung cancer. Given the large sample size of this analysis, we were able to perform subgroup analyses examining risk by gender, race/ethnicity, histologic type, age at diagnosis, and smoking status.

\section{Materials and Methods}

\section{Study Population}

The International Lung Cancer Consortium (ILCCO) was established in 2004, with the goal of sharing compatible data from lung cancer epidemiology studies to achieve greater power than from single studies alone. To date, 57 lung cancer studies are included in ILCCO. Further details regarding the aims, guidelines and policies of ILCCO are described in Hung et al.(15).

To be included in the main analysis of familial aggregation of lung cancer, the following minimum criteria were set. Each study must have collected data regarding the lung cancer status, age at diagnosis, smoking status of the proband, and vital status (living/deceased) for the mother, father and siblings of every case and control proband. Additional analyses were performed in 5 studies that also collected smoking status on each relative in addition to the 
minimum variables. Institutional approval and written informed consent from all subjects were obtained by the investigator at each study site for each original study and their deidentified data were submitted to ILCCO for pooling.

\section{Statistical Methods}

The individual-level data from each study included the following demographic variables for the case and control subjects (referred to as probands): gender, ethnicity, age at diagnosis (cases) or interview (controls), education, smoking status, and pack years smoked, and histological classification (cases only). Never smokers were individuals who reported smoking less than 100 cigarettes in their lifetime. Former smokers were individuals who reported smoking cessation at least 2 years prior to interview. Questions regarding these data were resolved by the original study investigator.

Relative risks of lung cancer associated with having a first-degree relative with lung cancer were assessed using unconditional logistic regression models to calculate odds ratios (ORs) and $95 \%$ confidence intervals. Estimates were adjusted for variables that differed significantly between probands or have been previously shown to be associated with lung cancer (gender, education, ethnicity, smoking status, pack years) and for study site. Logistic regression models were created for having any first degree relative with lung cancer, and then stratified by relative type (father, mother, sibling). To examine interactions between family history and race, a multiplicative variable of these two factors was added to the regression model. For all subgroup analyses except for histology, the controls were restricted to those from the same population (e.g., in the Asian subgroup analysis, only Asian controls were used). For histology subgroups, all controls $(n=23305)$ were used. For the sub-set of studies where individual-level information was collected on both affected and unaffected fathers, mothers, and siblings, in addition to the probands, generalized estimating equation (GEE) regression models were created to determine whether familial risk of lung cancer was present after adjustment for risk factors among the relatives of the probands. These models correct for the correlation between family members (16), and adjusted for gender and smoking status of each first-degree relative. First, the dataset was restricted to first-degree relatives, and a variable to indicate whether each individual was related to a case or control proband was assigned to each subject. GEE models were then constructed for estimating relative risks in case relatives compared to control relatives, adjusting for proband age, proband gender, gender of the relative, smoking status of the proband and smoking status of the relative. SAS (Cary, NC) Version 9.2 was used for all analyses.

\section{Results}

Information regarding family history of cancer in first-degree relatives was available for 24,380 cases and 23,399 controls. Of the 57 studies which have contributed data to ILCCO, 24 studies met inclusion criteria for the analysis. Studies from North America accounted for $54 \%$ of the datasets analyzed $(\mathrm{n}=13), 8$ were from Europe and 3 were from Asia and Oceania (Table 1). Population-based controls were ascertained by 11 studies, 8 studies employed hospital-based controls, and 5 studies utilized both population and hospital-based control probands (mixed).

Table 2 describes characteristics of case and control probands included in the analysis. Men accounted for about half of the study population, and the majority of the population was white (82.3\%), followed by Asian (6.8\%), and African American (5.4\%). Case probands were significantly more likely to be smokers compared to the control probands (pvalue $<0.0001$ ), and among those who reported smoking, cases had a higher number of pack years compared to controls ( $\mathrm{p}$-value $<0.0001$ ). 
Risk of lung cancer associated with having a family history of lung cancer in a first-degree relative (mother, father, sibling) is presented in Table 3. Associations between lung cancer and family history were found in nearly every stratum after adjusting for proband age, proband gender, ethnicity, education, smoking status of the proband, pack years, and study number. Overall, individuals with a first-degree relative with lung cancer had a 1.51-fold increase in risk of lung cancer compared to individuals without a family history, after adjustment (95\% CI: 1.39-1.63). There is evidence of interaction between smoking status and family history of lung cancer, with ever smoking individuals with a family history of lung cancer in a first degree relative having a 3.19-fold increase in risk of lung cancer compared to never smokers without a first-degree family history of lung cancer after adjustment (95\% CI: 2.03-5.00, data not shown). When stratified by relative type, the association was greatest for those with a history of lung cancer in a sibling $(\mathrm{OR}=1.82,95 \%$ CI: $1.62,2.05)$, compared to lung cancer in a father $(\mathrm{OR}=1.25,95 \% \mathrm{CI}: 1.13,1.39)$ or mother (OR=1.37 95\% CI: 1.17, 1.61). This pattern was similar in male and female probands. There was a significant interaction between race and family history of lung cancer $(\mathrm{p}=0.002$, data not shown). The overall association was strongest among Asians $(\mathrm{OR}=2.38$, 95\% CI: 1.50, 3.82), then African Americans (OR=1.67, 95\% CI: 1.16, 2.40) and whites (OR=1.46 95\% CI: $1.34,1.58)$. A family history of lung cancer was associated with lung cancer in every histological type examined, after adjustment. Among never smoking individuals, only a history of lung cancer in a sibling was associated with lung cancer $(\mathrm{OR}=1.44,95 \% \mathrm{CI}: 1.07,1.93)$. For ever smokers, lung cancer was associated with history of lung cancer in a father $(\mathrm{OR}=1.27,95 \% \mathrm{CI}: 1.13,1.43)$, mother $(\mathrm{OR}=1.40,95 \% \mathrm{CI}: 1.17$, 1.66) and sibling ( $\mathrm{OR}=1.91,95 \% \mathrm{CI}: 1.68,2.17)$, after adjustment. The association was stronger in cases diagnosed before the age of 50 than in later onset patients $(\mathrm{OR}=1.83$ and 1.45 , respectively). Having a history of lung cancer in siblings among probands $<50$ years old strengthened the association even further (OR=3.72, 95\% CI: 2.00, 6.90), double the odds ratio for the older cases (OR=1.86, 95\% CI: 1.65, 2.09). The number of affected relatives among cases and controls, by strata, are available in Supplementary Table 1.

The association between lung cancer and family history increased as the number of firstdegree relatives with lung cancer increased. The association between family history and lung cancer increased from 1.45 (95\% CI: 1.34, 1.58) for those individuals who reported one first-degree relative with lung cancer to $1.97(95 \% \mathrm{CI}: 1.59,2.45)$ for those individuals with 2 or more first-degree affected relatives (data not shown).

Tables 4 and 5 include studies where individual-level information was collected on both affected and unaffected fathers, mothers, and siblings, in addition to the probands. As seen in Table 4, data were available for mothers of 6297 cases and 5907 controls, with 240 case mothers having lung cancer (3.8\%) and 171 control mothers having lung cancer (2.9\%). Data were also available for 6,263 fathers of cases and 5,886 fathers of controls, with 453 case fathers having lung cancer (7.2\%) and 363 control fathers having lung cancer (6.2\%). Data were available for 18,948 siblings of cases and 16,625 siblings of controls, with 724 case siblings reported to have lung cancer (3.8\%) and 282 control siblings reported to have lung cancer $(1.7 \%)$. Similar mean ages at diagnosis were reported for case and control fathers ( $p$-value $=0.16)$, mothers $(p$-value $=0.08)$ and siblings $(p$-value $=0.72)$.

Table 5 presents the strength of familial aggregation of lung cancer after adjusting for proband age, proband gender, proband smoking status, relative's gender, and relative's smoking status. The association with family history was 1.55 -fold greater in first-degree relatives of cases compared to relatives of controls (95\% CI: 1.39, 1.73), after adjustment. The association between lung cancer and family history was elevated for case relatives in all subgroups compared to control relatives. Family history was a stronger risk factor for relatives of early-onset $(<50$ years of age) cases $(\mathrm{OR}=1.97,95 \% \mathrm{CI}$ : $1.51,2.58)$ than for 
those related to someone with later onset disease ( $\mathrm{OR}=1.53,95 \% \mathrm{CI}: 1.36,1.72)$. The association was greater for those who had a sibling with lung cancer $(\mathrm{OR}=1.96,95 \% \mathrm{CI}$ : $1.65,2.34)$ compared to a father $(\mathrm{OR}=1.33,95 \% \mathrm{CI}: 1.13,1.57)$ or mother $(\mathrm{OR}=1.39,95 \%$ CI: $1.12,1.75)$ with the disease. In a sub-analysis of siblings with never smoking parents, the association between having a first-degree relative with lung cancer and lung cancer risk remained $(\mathrm{OR}=2.18,95 \% \mathrm{CI}$ : 1.52-3.11) after adjustment (data not shown). Never smoking relatives of cases were somewhat more likely to have lung cancer compared to never smoking relatives of controls $(\mathrm{OR}=1.31,95 \% \mathrm{CI}$ : $0.96,1.78)$, but this association was not statistically significant. Individuals who were ever smokers and related to a case were 1.57fold more likely to have lung cancer than smokers who were related to a control (95\% CI: $1.41,1.76)$.

\section{Discussion}

The results presented here represent the most comprehensive analysis of the association between family history of lung cancer and lung cancer since the first strong evidence of familial aggregation was reported nearly 50 years ago (17). To date, this is the largest pooled analysis which incorporated a traditional case-control analysis and also used data from individual family members to examine risk adjusted for gender and smoking status of each relative. Individuals with family history in a first-degree relative are at an approximate 50\% increased risk of lung cancer compared to those without a family history, and this association remains regardless of gender, race/ethnicity, histological type and after adjusting for other known lung cancer risk factors.

The majority of lung cancers are diagnosed in current or former smokers, and environmental tobacco smoke also increases risk $(18,19)$. Given the strong evidence linking lung cancer etiology to well-identified occupational or environmental sources, less research has focused on other causes of this disease, including the influence of family history. Twin studies, especially those that can compare concordance between monozygotic and dizygotic twins, can provide information on whether familial aggregation is due to inherited or environmental factors. Evidence of limited heritability of lung cancers has been reported from population-based registry data in Utah, Sweden, Denmark and Finland (20-22). Even in these large, population-based studies, power is limited for most cancers, including lung. The magnitude of risk associated with having a family history of lung cancer are similar to those associated with familial aggregation of colon cancer (23), prostate cancer (24), and breast cancer in non-BRCA families (25). Stronger associations have been reported when the relative had early-onset disease for these cancers $(23,26,27)$, as well as for lung cancer (28-30). In this pooled analysis, the association was stronger for individuals who were diagnosed with lung cancer prior to age 50, or who had a family history of lung cancer in a relative under the age 50 . The difference was most pronounced among siblings, with the odds in early-onset lung cancer nearly double the odds in later onset probands.

Overall, having a sibling with lung cancer conferred the strongest association, and siblings of cases were at increased risk compared to siblings of controls. Aggregation studies of other cancer types such as prostate $(31,32)$ and breast $(25)$ also report evidence of a stronger association with affected siblings compared to parents, yet this is less established for colon cancer (33). The association between family history and lung cancer remained for siblings even after adjustment for cigarette smoking in the relative. Similarly, among never smoking probands, the association was greater for those who report lung cancer in a sibling, rather than a parent. The association also remained in siblings from non-smoking households (i.e. both parents were never smokers). Finally, after adjustment for smoking in both the proband and the sibling, there remained strong evidence of an association between family history and lung cancer in the siblings of cases compared to the siblings of controls. Relative type 
should be considered when assessing risk associated with family history of lung cancer. In general, an elevated risk of disease in siblings signals a recessive effect (34). The elevated risk from affected siblings might be a result from shared environment exposures childhood, or indicate there are recessive genes involved. In the five studies that provided information on all siblings, cases were not more likely to have a sibling compared to controls $(82.4 \%$ and $83.8 \%$, respectively), and sibships were similar in size, with an average of three siblings for both cases and controls. Adjusting for number of siblings did not change our results.

Nevertheless, another factor that needs to be considered when interpreting the strong sibling risk is the age distribution, as affected siblings often have younger ages of onset compared to the affected parents of the case probands. In our study, the mean age of diagnosis for affected siblings and affected parents of the index cases was 60.2 and 66.2, respectively. Therefore, the stronger familial relative risks observed in siblings might be partially associated with an earlier age of onset. These findings may also be the result of the proband having greater recall of the cancer status of their generation (versus their parent's generation) and better diagnostic techniques in later years, but could also represent evidence of the genetic contribution to lung cancer etiology.

Most studies of lung cancer and familial aggregation included mainly non-small cell lung cancers. While it is difficult to ascertain the histology of lung cancer in the relatives, we were able to ascertain the histological type of lung cancer for the probands and to stratify results according to type. Despite the different etiologies and outcomes associated with various histological types, the odds ratios fell in a fairly narrow range (ORrange 1.28-1.81). For example, the rare $(\sim 1 \%)$ carcinoid tumors of the lung, which are not considered to be smoking-associated and are characterized by an excellent overall survival (35), showed an association with a positive family history of lung cancer (OR=1.28, 95\% CI: 1.13-1.45), confirming in a large dataset early reports from Hassan et al. (2008)(36). The association with more common $(15 \%)$ and lethal small cell carcinomas $(37,38)$ is slightly higher $(\mathrm{OR}=1.51,95 \%$ CI: $1.33,1.70)$, as anticipated by a recent meta-analysis (39). Overall, the similar magnitudes of the effect of family history on lung cancer across various histological types suggest that familial aggregation may be independent of the association with cigarette smoking. The hypothesis that familial aggregation of lung cancer may be associated with traits which act independently of cigarette smoking has received support from the results of a follow up study of the chromosome $6 \mathrm{q}$ region which reports a lung cancer risk-associated haplotype irrespective of degree of smoking yielded similar risk in carriers (40). The search for other risk factors unrelated to smoking remains crucial, given the number of lung cancer seen among never smokers.

Global estimates suggest that approximately $25 \%$ of lung cancer cases world-wide occur among never smoking individuals $(41,42)$. In this analysis, approximately $14 \%$ of all lung cancers were diagnosed in never smokers, and family history of lung cancer was associated with having lung cancer. Various other exposures that were unmeasured in these populations may account for some of this risk, although studies among never smokers with lung cancer, even after adjusting for other known carcinogenic exposures, support family history as an important risk factor (43-45).

The association between having a family history of lung cancer in a first-degree relative and lung cancer varies by ethnicity. The associations were highest among Asians and lowest among whites, with estimates for African Americans falling in between. While some studies have reported differences in risk of lung cancer associated with cigarette smoking by race/ ethnicity, (46-48) few report estimates for family history by race/ethnicity, as study populations of individual studies are relatively homogenous. In the current pooled analysis, odds ratios were higher for African Americans, but not statistically different from results in the white populations. Studies investigating Asian populations reported risk estimates for 
familial aggregation of lung cancer similar to the 2-fold increases found in the present pooled analysis $(49,50)$. Lower background rates of disease may account for these apparently stronger associations in the Asian population. As smoking patterns, environmental and occupational exposures, diet, and genetics differ by race/ethnicity, it is not unexpected that the strength of the association between family history and lung cancer risk would also vary.

The findings presented are not without limitations. First, all studies relied on self-report of family history and thus may be prone to recall bias. Confirming each lung cancer among relatives would be ideal but time and cost-prohibitive. Studies that have validated the reported family history through another source consistently report high accuracy (sensitivity $>0.80$ ) for lung cancers (51-53). Similarly, we were unable to perform a standardized pathologic review to confirm histological type, in the probands or the affected relatives. Next, the methodologies used to ascertain controls differed among the studies. When we limited our analyses to studies using the same control source, findings were essentially the same. Only parents and siblings are included in our analysis, as six studies did not collect information on offspring, and another two studies were focused on early-onset disease, where the majority of the offspring were under 21 years of age. Lastly, pooled analyses are limited by the number of common variables collected by each study. Age, gender, ethnicity, education and smoking history were collected for all study subjects, which are the major known risk factors for lung cancer. It is possible that there remains residual confounding by smoking, as smoking status does not fully assess tobacco smoke exposure. Information on environmental tobacco smoke exposure (in childhood or as an adult) was not collected in a uniform manner, therefore we were not able to adjust for it in a standardize manner, hence our findings may be confounded by this omission. Relative information was more likely to be missing certain variables compared to proband data, and we did not adjust models for family size, as this was not available for the majority of the studies. When we restricted our analyses to those studies with a family size variable, the results were not significantly different.

In summary, family history is a simple proxy for genetic risk, and is influenced by both shared and individual environmental exposures. The association between lung cancer and family history of lung cancer remains even after adjustment for smoking. Unlike germline mutation testing, family history assessment is fairly straightforward and inexpensive to obtain while taking a patient's history. While the role of genetic variation in the etiology of lung cancer is not yet defined, family history assessment is immediately available and those with a positive history represent a higher risk group. A positive family history of lung cancer should possibly be one of the variables considered in the selection of a population eligible for lung cancer screening.

\section{Supplementary Material}

Refer to Web version on PubMed Central for supplementary material.

\section{Acknowledgments}

Drs. Cote, Liu, Etzel and Hung had full access to all of the data in the study and take responsibility for the integrity of the data and the accuracy of the data analysis.

The contributions of the following individuals: Christa Stegmaier, Hartwig Ziegler, Sonja Wolf and Volker Herrmann (ESTHER study) Urvi Mujumdar and Radhai Rastogi (MSKCC), Lynda Forbes, Yvonne Bush, Kelly Montgomery and Angela Wenzlaff (WSU), Dr. Tomas Lynch and Dr. John Wain, (Mass General Hosp), Dr. Kofi Asomaning and Ms. Andrea Shafer (Harvard School of Public Health) are gratefully acknowledged.

They do wish to acknowledge the following support: 
ILCCO data management is supported by Canadian Cancer Society (CCSRI no. 020214) and Cancer Care Ontario Research Chair Award.

MLC: NIH K07 CA125203-01A2

AGS: NIH R01CA060691, NIH R01CA87895, NIH N01-PC35145, NIH P30CA22453

DCC: Grants: NIH (NCI) RO1CA74386 and P50 CA090578

GR: Grant number 2003159 from the Bi-national Israel US Science Foundation (BSF)

HB and HM: ESTHER study was supported by a grant from the Baden-Württemberg Ministry of Science Research and Arts.

IO: Steps for Breath and the Labrecque Foundation; and the Society of Memorial Sloan-Kettering Cancer Center

JL: The Warsaw study part of the study was supported by local grant from The Polish State Committee for Scientific Research, grant no. SPUBM-COPERNICUS/P-05/DZ-30/99/2000.

PJW: ReSoLuCENT study funded by the Weston Park Hospital Charitable Trust

Financial support from European Commission (DG-XII), contract no. IC15-CT96-0313 is gratefully acknowledged.

The Nijmegen Ling Cancer Study was funded by an investment grant of the Radboud University Nijmegen Medical Centre.

\section{References}

1. Ferlay J, Shin HR, Bray F, Forman D, Mathers C, Parkin DM. Estimates of worldwide burden of cancer in 2008: GLOBOCAN. Int J Cancer. Jun 17.2008

2. Jemal A, Siegel R, Ward E, Hao Y, Xu J, Murray T, et al. Cancer statistics, 2008. CA Cancer J Clin. Mar-Apr;2008 58(2):71-96. [PubMed: 18287387]

3. United States Department of Health and Human Services. Department of Health and Human Services Centers for Disease Control and Prevention. National Center for Chronic Disease Prevention and Health Promotion; Atlanta, GA: 2004. The Health Consequences of Smoking: A Report of the Surgeon General.

4. Amos CI, Wu X, Broderick P, Gorlov IP, Gu J, Eisen T, et al. Genome-wide association scan of tag SNPs identifies a susceptibility locus for lung cancer at 15q25.1. Nat Genet. May; 2008 40(5):61622. [PubMed: 18385676]

5. Hung RJ, McKay JD, Gaborieau V, Boffetta P, Hashibe M, Zaridze D, et al. A susceptibility locus for lung cancer maps to nicotinic acetylcholine receptor subunit genes on 15q25. Nature. Apr 3; 2008 452(7187):633-7. [PubMed: 18385738]

6. Thorgeirsson TE, Geller F, Sulem P, Rafnar T, Wiste A, Magnusson KP, et al. A variant associated with nicotine dependence, lung cancer and peripheral arterial disease. Nature. Apr 3; 2008 452(7187):638-42. [PubMed: 18385739]

7. Liu P, Vikis HG, Wang D, Lu Y, Wang Y, Schwartz AG, et al. Familial aggregation of common sequence variants on 15q24-25.1 in lung cancer. J Natl Cancer Inst. Sep 17; 2008 100(18):1326-30. [PubMed: 18780872]

8. Bailey-Wilson JE, Amos CI, Pinney SM, Petersen GM, de Andrade M, Wiest JS, et al. A major lung cancer susceptibility locus maps to chromosome 6q23-25. Am J Hum Genet. Sep; 2004 75(3):46074. [PubMed: 15272417]

9. D’Amelio AM Jr. Cassidy A, Asomaning K, Raji OY, Duffy SW, Field JK, et al. Comparison of discriminatory power and accuracy of three lung cancer risk models. Br J Cancer. Jul 27; 2010 103(3):423-9. [PubMed: 20588271]

10. Reduced Lung-Cancer Mortality with Low-Dose Computed Tomographic Screening. N Engl J Med. Jun 29.2011

11. Peres J. Lung cancer screening: ready for prime time? J Natl Cancer Inst. Jan 19; 103(2):89-91. [PubMed: 21191112] 
12. National Cancer Institute. PDQ Lung Cancer Prevention. Bethesda, MD: 2010.

13. Gu J, Hua F, Zhong D, Chen J, Liu H, Zhou Q. [Systematic review of the relationship between family history of lung cancer and lung cancer risk]. Zhongguo Fei Ai Za Zhi. Mar; 2010 13(3): 224-9. [PubMed: 20673520]

14. Matakidou A, Eisen T, Houlston RS. Systematic review of the relationship between family history and lung cancer risk. Br J Cancer. Oct 3; 2005 93(7):825-33. [PubMed: 16160696]

15. Hung RJ, Christiani DC, Risch A, Popanda O, Haugen A, Zienolddiny S, et al. International Lung Cancer Consortium: pooled analysis of sequence variants in DNA repair and cell cycle pathways. Cancer Epidemiol Biomarkers Prev. Nov; 2008 17(11):3081-9. [PubMed: 18990748]

16. Zeger SL, Liang KY. Longitudinal data analysis for discrete and continuous outcomes. Biometrics. Mar; 1986 42(1):121-30. [PubMed: 3719049]

17. Tokuhata GK, Lilienfeld AM. Familial aggregation of lung cancer among hospital patients. Public Health Rep. 1963 Apr.78:277-83. [PubMed: 13985328]

18. Oberg M, Jaakkola MS, Woodward A, Peruga A, Pruss-Ustun A. Worldwide burden of disease from exposure to second-hand smoke: a retrospective analysis of data from 192 countries. Lancet. Jan 8; 2011 377(9760):139-46. [PubMed: 21112082]

19. Tong L, Spitz MR, Fueger JJ, Amos CA. Lung carcinoma in former smokers. Cancer. Sep 1; 1996 78(5):1004-10. [PubMed: 8780538]

20. Goldgar DE, Easton DF, Cannon-Albright LA, Skolnick MH. Systematic population-based assessment of cancer risk in first-degree relatives of cancer probands. J Natl Cancer Inst. Nov 2; 1994 86(21):1600-8. [PubMed: 7932824]

21. Hemminki K, Vaittinen P. Familial cancers in a nationwide family cancer database: age distribution and prevalence. Eur J Cancer. Jul; 1999 35(7):1109-17. [PubMed: 10533456]

22. Lichtenstein P, Holm NV, Verkasalo PK, Iliadou A, Kaprio J, Koskenvuo M, et al. Environmental and heritable factors in the causation of cancer--analyses of cohorts of twins from Sweden, Denmark, and Finland. N Engl J Med. Jul 13; 2000 343(2):78-85. [PubMed: 10891514]

23. Fuchs CS, Giovannucci EL, Colditz GA, Hunter DJ, Speizer FE, Willett WC. A prospective study of family history and the risk of colorectal cancer. N Engl J Med. Dec 22; 1994 331(25):1669-74. [PubMed: 7969357]

24. Steinberg GD, Carter BS, Beaty TH, Childs B, Walsh PC. Family history and the risk of prostate cancer. Prostate. 1990; 17(4):337-47. [PubMed: 2251225]

25. Pharoah PD, Day NE, Duffy S, Easton DF, Ponder BA. Family history and the risk of breast cancer: a systematic review and meta-analysis. Int J Cancer. May 29; 1997 71(5):800-9. [PubMed: 9180149]

26. Familial breast cancer: collaborative reanalysis of individual data from 52 epidemiological studies including 58,209 women with breast cancer and 101,986 women without the disease. Lancet. Oct 27; 2001 358(9291):1389-99. [PubMed: 11705483]

27. Keetch DW, Rice JP, Suarez BK, Catalona WJ. Familial aspects of prostate cancer: a case control study. J Urol. Dec; 1995 154(6):2100-2. [PubMed: 7500468]

28. Cassidy A, Balsan J, Vesin A, Wu X, Liloglou T, Brambilla C, et al. Cancer diagnosis in firstdegree relatives and non-small cell lung cancer risk: results from a multi-centre case-control study in Europe. Eur J Cancer. Nov; 2009 45(17):3047-53. [PubMed: 19482469]

29. Etzel CJ, Lu M, Merriman K, Liu M, Vaporciyan A, Spitz MR. An epidemiologic study of early onset lung cancer. Lung Cancer. May; 2006 52(2):129-34. [PubMed: 16564601]

30. Kreuzer M, Kreienbrock L, Gerken M, Heinrich J, Bruske-Hohlfeld I, Muller KM, et al. Risk factors for lung cancer in young adults. Am J Epidemiol. Jun 1; 1998 147(11):1028-37. [PubMed: 9620046]

31. Cerhan JR, Parker AS, Putnam SD, Chiu BC, Lynch CF, Cohen MB, et al. Family history and prostate cancer risk in a population-based cohort of Iowa men. Cancer Epidemiol Biomarkers Prev. Jan; 1999 8(1):53-60. [PubMed: 9950240]

32. Lesko SM, Rosenberg L, Shapiro S. Family history and prostate cancer risk. Am J Epidemiol. Dec 1; 1996 144(11):1041-7. [PubMed: 8942435]

33. Johns LE, Houlston RS. A systematic review and meta-analysis of familial colorectal cancer risk. Am J Gastroenterol. Oct; 2001 96(10):2992-3003. [PubMed: 11693338] 
34. Ott, J. Analysis of human genetic linkage. 3rd ed. The Johns Hopkins University Press; Baltimore, MD: 1999.

35. Bertino EM, Confer PD, Colonna JE, Ross P, Otterson GA. Pulmonary neuroendocrine/carcinoid tumors: a review article. Cancer. Oct 1; 2009 115(19):4434-41. [PubMed: 19562772]

36. Hassan MM, Phan A, Li D, Dagohoy CG, Leary C, Yao JC. Family history of cancer and associated risk of developing neuroendocrine tumors: a case-control study. Cancer Epidemiol Biomarkers Prev. Apr; 2008 17(4):959-65. [PubMed: 18398037]

37. Atlekruse, SF.; Kosary, CL.; Krapcho, M., et al. [cited based on November 2009] SEER Cancer Statistics Review, 1975-2007. 2010. SEER data submission, posted to the SEER web site, 2010; Available from: http://seer.cancer.gov/csr/1975_2007/

38. Brownson RC, Chang JC, Davis JR. Gender and histologic type variations in smoking-related risk of lung cancer. Epidemiology. Jan; 1992 3(1):61-4. [PubMed: 1313311]

39. Lissowska J, Foretova L, Dabek J, Zaridze D, Szeszenia-Dabrowska N, Rudnai P, et al. Family history and lung cancer risk: international multicentre case-control study in Eastern and Central Europe and meta-analyses. Cancer Causes Control. Jul; 2010 21(7):1091-104. [PubMed: 20306329]

40. Amos CI, Pinney SM, Li Y, Kupert E, Lee J, de Andrade MA, et al. A susceptibility locus on chromosome 6q greatly increases lung cancer risk among light and never smokers. Cancer Res. Mar 15; 2010 70(6):2359-67. [PubMed: 20215501]

41. Parkin DM, Bray F, Ferlay J, Pisani P. Global cancer statistics, 2002. CA Cancer J Clin. Mar-Apr; 2005 55(2):74-108. [PubMed: 15761078]

42. Sun S, Schiller JH, Gazdar AF. Lung cancer in never smokers--a different disease. Nat Rev Cancer. Oct; 2007 7(10):778-90. [PubMed: 17882278]

43. Schwartz AG, Yang P, Swanson GM. Familial risk of lung cancer among nonsmokers and their relatives. Am J Epidemiol. Sep 15; 1996 144(6):554-62. [PubMed: 8797515]

44. Wu AH, Fontham ET, Reynolds P, Greenberg RS, Buffler P, Liff J, et al. Family history of cancer and risk of lung cancer among lifetime nonsmoking women in the United States. Am J Epidemiol. Mar 15; 1996 143(6):535-42. [PubMed: 8610670]

45. Wu PF, Lee CH, Wang MJ, Goggins WB, Chiang TA, Huang MS, et al. Cancer aggregation and complex segregation analysis of families with female non-smoking lung cancer probands in Taiwan. Eur J Cancer. Jan; 2004 40(2):260-6. [PubMed: 14728941]

46. Harris RE, Zang EA, Anderson JI, Wynder EL. Race and sex differences in lung cancer risk associated with cigarette smoking. Int J Epidemiol. Aug; 1993 22(4):592-9. [PubMed: 8225730]

47. Hinds MW, Stemmermann GN, Yang HY, Kolonel LN, Lee J, Wegner E. Differences in lung cancer risk from smoking among Japanese, Chinese and Hawaiian women in Hawaii. Int J Cancer. Mar 15; 1981 27(3):297-302. [PubMed: 7287220]

48. Le Marchand L, Wilkens LR, Kolonel LN. Ethnic differences in the lung cancer risk associated with smoking. Cancer Epidemiol Biomarkers Prev. Jan-Feb;1992 1(2):103-7. [PubMed: 1306091]

49. Nitadori J, Inoue M, Iwasaki M, Otani T, Sasazuki S, Nagai K, et al. Association between lung cancer incidence and family history of lung cancer: data from a large-scale population-based cohort study, the JPHC study. Chest. Oct; 2006 130(4):968-75. [PubMed: 17035426]

50. Wang XR, Yu IT, Chiu YL, Qiu H, Fu Z, Goggins W, et al. Previous pulmonary disease and family cancer history increase the risk of lung cancer among Hong Kong women. Cancer Causes Control. Jul; 2009 20(5):757-63. [PubMed: 19169896]

51. Chang ET, Smedby KE, Hjalgrim H, Glimelius B, Adami HO. Reliability of self-reported family history of cancer in a large case-control study of lymphoma. J Natl Cancer Inst. Jan 4; 2006 98(1): 61-8. [PubMed: 16391372]

52. Douglas FS, O'Dair LC, Robinson M, Evans DG, Lynch SA. The accuracy of diagnoses as reported in families with cancer: a retrospective study. J Med Genet. Apr; 1999 36(4):309-12. [PubMed: 10227399]

53. Soegaard M, Jensen A, Frederiksen K, Hogdall E, Hogdall C, Blaakaer J, et al. Accuracy of selfreported family history of cancer in a large case-control study of ovarian cancer. Cancer Causes Control. Jun; 2008 19(5):469-79. [PubMed: 18197461] 
54. Brenner DR, Hung RJ, Tsao MS, Shepherd FA, Johnston MR, Narod S, et al. Lung cancer risk in never-smokers: a population-based case-control study of epidemiologic risk factors. BMC Cancer. Jun 14.2010 10(1):285. [PubMed: 20546590]

55. Aldrich MC, Selvin S, Hansen HM, Barcellos LF, Wrensch MR, Sison JD, et al. CYP1A1/2 haplotypes and lung cancer and assessment of confounding by population stratification. Cancer Res. Mar 15; 2009 69(6):2340-8. [PubMed: 19276377]

56. Li Y, Sun Z, Wu Y, Babovic-Vuksanovic D, Cunningham JM, Pankratz VS, et al. Cystic fibrosis transmembrane conductance regulator gene mutation and lung cancer risk. Lung Cancer. Jan 28.2010

57. Zhai R, Liu G, Zhou W, Su L, Heist RS, Lynch TJ, et al. Vascular endothelial growth factor genotypes, haplotypes, gender, and the risk of non-small cell lung cancer. Clin Cancer Res. Jan 15; 2008 14(2):612-7. [PubMed: 18223238]

58. Etzel CJ, Amos CI, Spitz MR. Risk for smoking-related cancer among relatives of lung cancer patients. Cancer Res. Dec 1; 2003 63(23):8531-5. [PubMed: 14679021]

59. Cote ML, Kardia SL, Wenzlaff AS, Ruckdeschel JC, Schwartz AG. Risk of lung cancer among white and black relatives of individuals with early-onset lung cancer. JAMA. Jun 22; 2005 293(24):3036-42. [PubMed: 15972566]

60. Cote ML, Yoo W, Wenzlaff AS, Prysak GM, Santer SK, Claeys GB, et al. Tobacco and estrogen metabolic polymorphisms and risk of non-small cell lung cancer in women. Carcinogenesis. Apr; 2009 30(4):626-35. [PubMed: 19174490]

61. Muscat JE, Chen SQ, Richie JP Jr. Altorki NK, Citron M, Olson S, et al. Risk of lung carcinoma among users of nonsteroidal antiinflammatory drugs. Cancer. Apr 1; 2003 97(7):1732-6. [PubMed: 12655530]

62. Cui Y, Morgenstern H, Greenland S, Tashkin DP, Mao J, Cao W, et al. Polymorphism of Xeroderma Pigmentosum group $\mathrm{G}$ and the risk of lung cancer and squamous cell carcinomas of the oropharynx, larynx and esophagus. Int J Cancer. Feb 1; 2006 118(3):714-20. [PubMed: 16094634]

63. Zheng YL, Loffredo CA, Yu Z, Jones RT, Krasna MJ, Alberg AJ, et al. Bleomycin-induced chromosome breaks as a risk marker for lung cancer: a case-control study with population and hospital controls. Carcinogenesis. Feb; 2003 24(2):269-74. [PubMed: 12584177]

64. Gallagher CJ, Muscat JE, Hicks AN, Zheng Y, Dyer AM, Chase GA, et al. The UDPglucuronosyltransferase $2 \mathrm{~B} 17$ gene deletion polymorphism: sex-specific association with urinary 4-(methylnitrosamino)-1-(3-pyridyl)-1-butanol glucuronidation phenotype and risk for lung cancer. Cancer Epidemiol Biomarkers Prev. Apr; 2007 16(4):823-8. [PubMed: 17416778]

65. Heck JE, Andrew AS, Onega T, Rigas JR, Jackson BP, Karagas MR, et al. Lung cancer in a U.S. population with low to moderate arsenic exposure. Environ Health Perspect. Nov; 2009 117(11): 1718-23. [PubMed: 20049123]

66. Orlow I, Park BJ, Mujumdar U, Patel H, Siu-Lau P, Clas BA, et al. DNA damage and repair capacity in patients with lung cancer: prediction of multiple primary tumors. J Clin Oncol. Jul 20; 2008 26(21):3560-6. [PubMed: 18640936]

67. Richiardi L, Boffetta P, Simonato L, Forastiere F, Zambon P, Fortes C, et al. Occupational risk factors for lung cancer in men and women: a population-based case-control study in Italy. Cancer Causes Control. Apr; 2004 15(3):285-94. [PubMed: 15090723]

68. Loriot MA, Rebuissou S, Oscarson M, Cenee S, Miyamoto M, Ariyoshi N, et al. Genetic polymorphisms of cytochrome P450 2A6 in a case-control study on lung cancer in a French population. Pharmacogenetics. Feb; 2001 11(1):39-44. [PubMed: 11207029]

69. Breitling LP, Dahmen N, Illig T, Rujescu D, Nitz B, Raum E, et al. Variants in COMT and spontaneous smoking cessation: retrospective cohort analysis of 925 cessation events. Pharmacogenet Genomics. Aug; 2009 19(8):657-9. [PubMed: 19584770]

70. Ugolini D, Neri M, Canessa PA, Casilli C, Catrambone G, Ivaldi GP, et al. The CREST biorepository: a tool for molecular epidemiology and translational studies on malignant mesothelioma, lung cancer, and other respiratory tract diseases. Cancer Epidemiol Biomarkers Prev. Nov; 2008 17(11):3013-9. [PubMed: 18990743] 
71. Rafnar T, Sulem P, Stacey SN, Geller F, Gudmundsson J, Sigurdsson A, et al. Sequence variants at the TERT-CLPTM1L locus associate with many cancer types. Nat Genet. Feb; 2009 41(2):221-7. [PubMed: 19151717]

72. Field JK, Smith DL, Duffy S, Cassidy A. The Liverpool Lung Project research protocol. Int J Oncol. Dec; 2005 27(6):1633-45. [PubMed: 16273220]

73. Woll, P. http://resolucent.group.shef.ac.uk. [cited; Available from:http:// resolucent.group.shef.ac.uk

74. Park JY, Matsuo K, Suzuki T, Ito H, Hosono S, Kawase T, et al. Impact of smoking on lung cancer risk is stronger in those with the homozygous aldehyde dehydrogenase 2 null allele in a Japanese population. Carcinogenesis. Apr; 2010 31(4):660-5. [PubMed: 20093384]

75. Kiyohara C, Yamamura KI, Nakanishi Y, Takayama K, Hara N. Polymorphism in GSTM1, GSTT1, and GSTP1 and Susceptibility to Lung Cancer in a Japanese Population. Asian Pac J Cancer Prev. 2000; 1(4):293-8. [PubMed: 12716303]

76. Le Marchand L, Donlon T, Lum-Jones A, Seifried A, Wilkens LR. Association of the hOGG1 Ser326Cys polymorphism with lung cancer risk. Cancer Epidemiol Biomarkers Prev. Apr; 2002 11(4):409-12. [PubMed: 11927502] 
Table 1

Description of the studies included in the pooled analysis of familial aggregation of lung cancer

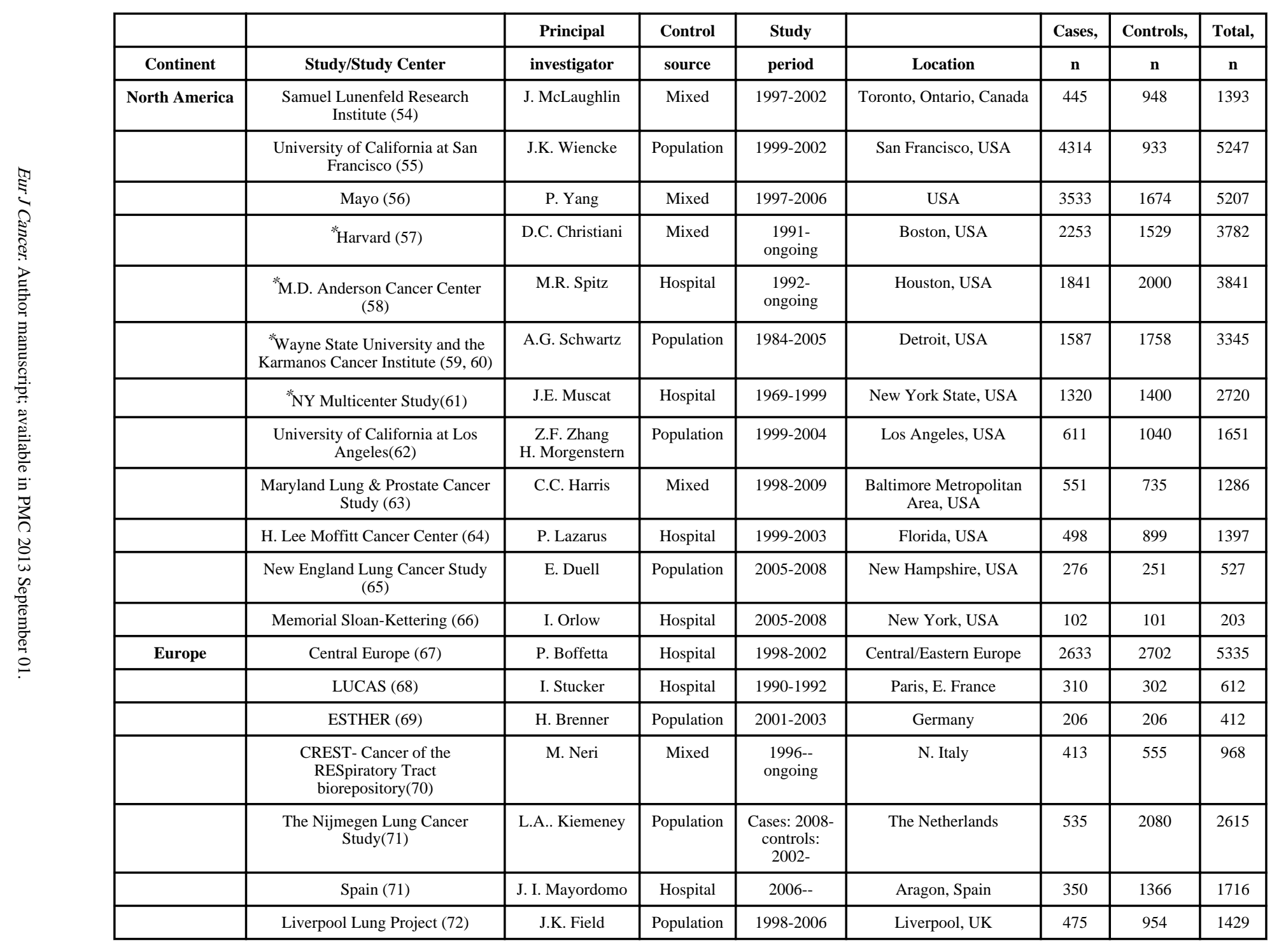




\begin{tabular}{|c|c|c|c|c|c|c|c|c|}
\hline & & Principal & Control & Study & & Cases, & Controls, & Total, \\
\hline Continent & Study/Study Center & investigator & source & period & Location & $\mathrm{n}$ & $\mathbf{n}$ & $\mathbf{n}$ \\
\hline & ReSoLuCENT (73) & P.J. Woll & Population & $\begin{array}{c}2006- \\
\text { ongoing }\end{array}$ & N. Trent, UK & 214 & 204 & 418 \\
\hline $\begin{array}{l}\text { Asia and } \\
\text { Oceania }\end{array}$ & Aichi (74) & K. Matsuo & Hospital & $2001-2005$ & Japan & 716 & 716 & 1432 \\
\hline & Kyushu (75) & C. Kiyohara & Population & 1994-1996 & Japan & 190 & 108 & 298 \\
\hline & *Israel (29) & G. Rennert & Population & 2005-- & Israel & 372 & 350 & 722 \\
\hline & Hawaii (76) & L. Le Marchand & Population & 1992-1997 & Hawaii, USA & 635 & 588 & 1223 \\
\hline Total & & & & & & 24380 & 23399 & 47779 \\
\hline
\end{tabular}

* Data from these study sites were included in the generalized estimating equations analysis (Tables 4 and 5). Note that sample sizes reported in early manuscripts for published studies are often smaller than what was included in this pooled analysis. 
Table 2

Characteristics of probands included in the familial aggregation analysis

\begin{tabular}{|c|c|c|c|}
\hline & Cases $(n=24380)$ & Controls $(n=23305)$ & p-value \\
\hline \multicolumn{4}{|l|}{ Gender } \\
\hline Men & $13833(56.7 \%)$ & $12529(53.8 \%)$ & $<0.0001$ \\
\hline Women & $10547(43.3 \%)$ & $10776(46.2 \%)$ & \\
\hline \multicolumn{4}{|l|}{ Age } \\
\hline$<30$ & $73(0.3 \%)$ & $476(2.0 \%)$ & $<0.0001$ \\
\hline 30 śge $<40$ & $551(2.3 \%)$ & $1388(6.0 \%)$ & \\
\hline 40 snge $<50$ & $2551(10.5 \%)$ & $3236(13.9 \%)$ & \\
\hline 50 śge $<60$ & $5458(22.4 \%)$ & $5764(24.7 \%)$ & \\
\hline 60 śge $<70$ & $7813(32.3 \%)$ & $7012(30.1 \%)$ & \\
\hline 70 śge $<80$ & $6480(26.6 \%)$ & $4689(20.1 \%)$ & \\
\hline $80+$ & $1454(5.9 \%)$ & $740(3.2 \%)$ & \\
\hline \multicolumn{4}{|l|}{ Race/Ethnicity } \\
\hline White/Caucasian & $20069(82.3 \%)$ & $19303(82.8 \%)$ & $<0.0001$ \\
\hline Hispanic/Latino & $440(1.8 \%)$ & $670(2.9 \%)$ & \\
\hline African American & $1304(5.4 \%)$ & $1691(7.3 \%)$ & \\
\hline Asian & $1656(6.8 \%)$ & $1282(5.5 \%)$ & \\
\hline $\begin{array}{l}\text { American Indian and Alaskan } \\
\text { Native }\end{array}$ & $185(0.8 \%)$ & $33(0.1 \%)$ & \\
\hline Hawaiian/Pacific Islander & $398(1.6 \%)$ & $150(0.6 \%)$ & \\
\hline Other & $169(0.7 \%)$ & $152(0.7 \%)$ & \\
\hline Missing/Unknown & $159(0.7 \%)$ & $24(0.1 \%)$ & \\
\hline \multicolumn{4}{|l|}{ Education * } \\
\hline Low & $6332(26.0 \%)$ & $4550(19.5 \%)$ & $<0.0001$ \\
\hline Medium & $9023(37.0 \%)$ & $7800(33.5 \%)$ & \\
\hline High & $6459(26.5 \%)$ & $8513(36.5 \%)$ & \\
\hline Missing & $2566(10.5 \%)$ & $2442(10.5 \%)$ & \\
\hline \multicolumn{4}{|l|}{ Type of Smoker } \\
\hline Never & $3301(13.5 \%)$ & $8497(36.5 \%)$ & $<0.0001$ \\
\hline Ever $^{* * *}$ & $20961(86.0 \%)$ & $14160(60.8 \%)$ & \\
\hline Former & $7940(32.6 \%)$ & $7836(33.6 \%)$ & \\
\hline Current & $9877(40.5 \%)$ & $5287(22.7 \%)$ & \\
\hline Missing & $118(0.5 \%)$ & $648(2.8 \%)$ & \\
\hline Mean Pack Years ${ }^{\dagger}(\mathrm{SD})$ & $44.3(33.3)$ & $20.4(25.8)$ & $<0.0001$ \\
\hline \multicolumn{4}{|l|}{ Histology } \\
\hline Small cell carcinoma & $2358(9.7 \%)$ & & \\
\hline Non-small cell carcinomas $t$ & $18616(76.4 \%)$ & & \\
\hline Squamous cell carcinomas & $5781(23.7 \%)$ & & \\
\hline
\end{tabular}




\begin{tabular}{|l|c|l|l|}
\hline & Cases (n=24380) & Controls (n=23305) & p-value \\
\hline Large cell carcinomas & $1099(4.5 \%)$ & & \\
\hline Adenocarcinoma & $9285(38.1 \%)$ & & \\
\hline $\begin{array}{c}\text { Bronchioloalveolar carcinoma } \\
\text { (BAC) }\end{array}$ & $896(3.7 \%)$ & & \\
\hline $\begin{array}{c}\text { Non small cell carcinoma, not } \\
\text { otherwise specified }\end{array}$ & $1555(6.4 \%)$ & & \\
\hline Carcinoma $\xi$ & $1797(7.4 \%)$ & & \\
\hline Carcinoid & $347(1.4 \%)$ & & \\
\hline Others/missing & $1262(5.2 \%)$ & & \\
\hline
\end{tabular}

Low=less than high school, medium=high school diploma or equivalent or some college, high=college degree ***

Includes former smokers, current smokers, and subjects who were either former or current smokers

Pack years of smoking was missing for $9.61 \%$ of cases and $14.56 \%$ for controls

Fon-small cell includes squamous cell, large cell, adenocarcinomas, bronchioloalveolar carcinoma, and non-small cell carcinoma, not otherwise specified

$\xi_{\text {No further detail available }}$ 
Table 3

The association between family history of lung cancer and lung cancer, by relative type

\begin{tabular}{|c|c|c|c|c|}
\hline & $\begin{array}{l}\text { Family History of } \\
\text { Lung Cancer in } \\
\text { 1st Degree } \\
\text { Relative }\end{array}$ & $\begin{array}{l}\text { Family History of } \\
\text { Lung Cancer in } \\
\text { Father }\end{array}$ & $\begin{array}{l}\text { Family History of } \\
\text { Lung Cancer in } \\
\text { Mother }\end{array}$ & $\begin{array}{l}\text { Family History of } \\
\text { Lung Cancer in } \\
\text { Sibling }\end{array}$ \\
\hline & OR $(95 \% \mathrm{CI})$ & OR (95\% CI) & OR $(95 \% \mathrm{CI})$ & OR $(95 \% \mathrm{CI})$ \\
\hline Overall & $1.51(1.39,1.63)$ & $1.25(1.13,1.39)$ & $1.37(1.17,1.61)$ & $1.82(1.62,2.05)$ \\
\hline \multicolumn{5}{|l|}{ Proband Gender } \\
\hline Male & $1.53(1.37,1.70)$ & $1.23(1.06,1.43)$ & $1.32(1.05,1.66)$ & $2.07(1.76,2.45)$ \\
\hline Female & $1.48(1.33,1.65)$ & $1.27(1.09,1.48)$ & $1.43(1.15,1.77)$ & $1.59(1.35,1.87)$ \\
\hline \multicolumn{5}{|l|}{ Proband Ethnicity } \\
\hline White & $1.46(1.34,1.58)$ & $1.19(1.07,1.34)$ & $1.37(1.16,1.62)$ & $1.77(1.56,2.00)$ \\
\hline Black/African American & $1.67(1.16,2.40)$ & $1.48(0.87,2.54)$ & $1.13(0.55,2.30)$ & $2.07(1.19,3.60)$ \\
\hline Asian & $2.38(1.50,3.82)$ & $2.82(1.54,5.70)$ & $0.97(0.39,2.38)$ & $4.35(1.83,10.34)$ \\
\hline \multicolumn{5}{|l|}{ Proband Histology } \\
\hline Small cell carcinoma & $1.51(1.33,1.70)$ & $1.33(1.13,1.57)$ & $1.31(1.00,1.73)$ & $1.63(1.36,1.95)$ \\
\hline Non-small cell carcinoma & $1.58(1.44,1.73)$ & $1.40(1.23,1.59)$ & $1.28(1.07,1.54)$ & $1.77(1.55,2.02)$ \\
\hline $\begin{array}{l}\text { Squamous cell } \\
\text { carcinoma }\end{array}$ & $1.54(1.39,1.72)$ & $1.32(1.14,1.53)$ & $1.16(0.91,1.49)$ & $1.85(1.59,2.16)$ \\
\hline Large cell carcinoma & $1.81(1.60,2.06)$ & $1.55(1.30,1.92)$ & $1.58(1.25,2.10)$ & $1.23(1.78,2.56)$ \\
\hline Adenocarcinoma & $1.59(1.45,1.74)$ & $1.25(1.10,1.43)$ & $1.61(1.34,1.93)$ & $1.85(1.61,2.12)$ \\
\hline BAC & $1.56(1.45,1.69)$ & $1.09(0.90,1.35)$ & $1.68(1.24,2.12)$ & $1.93(1.64,2.70)$ \\
\hline $\begin{array}{l}\text { Non-small cell } \\
\text { carcinoma, nos Carcinoma }\end{array}$ & $1.78(1.58,2.01)$ & $1.48(1.24,1.75)$ & $2.24(1.78,2.83)$ & $1.73(1.44,2.08)$ \\
\hline Carcinoid & $1.28(1.13,1.45)$ & $0.92(0.69,1.10)$ & $1.48(1.16,1.92)$ & $1.78(1.48,2.42)$ \\
\hline Others/missing & $1.30(1.17,1.48)$ & $1.10(0.96,1.35)$ & $1.20(0.95,1.62)$ & $1.85(1.55,2.30)$ \\
\hline \multicolumn{5}{|l|}{ Proband Smoking Status } \\
\hline Never Smokers & $1.25(1.03,1.52)$ & $1.09(0.82,1.45)$ & $1.10(0.74,1.66)$ & $1.44(1.07,1.93)$ \\
\hline Ever Smokers & $1.55(1.42,1.68)$ & $1.27(1.13,1.43)$ & $1.40(1.17,1.66)$ & $1.91(1.68,2.17)$ \\
\hline Former Smokers & $1.46(1.29,1.65)$ & $1.23(1.03,1.47)$ & $1.26(0.97,1.62)$ & $1.83(1.53,2.18)$ \\
\hline Current Smokers & $1.57(1.37,1.79)$ & $1.33(1.11,1.59)$ & $1.51(1.15,1.99)$ & $1.85(1.48,2.32)$ \\
\hline \multicolumn{5}{|l|}{ Proband Age at Onset } \\
\hline$<50$ & $1.83(1.47,2.28)$ & $1.68(1.28,2.20)$ & $1.51(1.04,2.20)$ & $3.72(2.00,6.90)$ \\
\hline $50+$ & $1.45(1.33,1.57)$ & $1.10(0.97,1.24)$ & $1.27(1.06,1.52)$ & $1.86(1.65,2.09)$ \\
\hline
\end{tabular}

All ORs are adjusted for age, gender, ethnicity, education, smoker type, pack years and study site, where appropriate. 
Table 4

Characteristics of relatives included in the familial aggregation analysis using generalized estimating equations

\begin{tabular}{|l|c|c|c|}
\hline & Case Relatives & Control Relatives & P-value \\
\hline Mothers (n= 12204) & $\mathrm{n}=6297$ & $\mathrm{n}=5907$ & \\
\hline Ever Smoker & $2123(38.0 \%)$ & $2270(40.4 \%)$ & 0.009 \\
\hline Never Smoker & $3465(62.0 \%)$ & $3349(59.6 \%)$ & \\
\hline Number (\%) affected w/Lung cancer: & $240(3.8 \%)$ & $171(2.9 \%)$ & \\
\hline Median age at diagnosis & 68 & 70 & \\
\hline Mean age at diagnosis $( \pm$ SD) & $66.8 \pm 13.0$ & $69.0 \pm 10.4$ & 0.08 \\
\hline Missing age at diagnosis & $6(2.5 \%)$ & $4(2.3 \%)$ & 0.92 \\
\hline Fathers (n=12149) & 6263 & 5886 & \\
\hline Ever Smoker & $3945(72.7 \%)$ & $3939(72.2 \%)$ & 0.57 \\
\hline Never Smoker & $1483(27.3 \%)$ & $1517(27.8 \%)$ & \\
\hline Number (\%) affected w/Lung cancer: & $453(7.2 \%)$ & $363(6.2 \%)$ & \\
\hline Median age at diagnosis & 65 & 67 & \\
\hline Mean age at diagnosis $( \pm$ SD) & $64.8 \pm 10.4$ & $65.9 \pm 10.8$ & 0.16 \\
\hline Missing age at diagnosis & $27(6.0 \%)$ & $12(3.3 \%)$ & 0.08 \\
\hline Siblings (n= 35573) & 18948 & 16625 & \\
\hline Ever Smoker & $9869(59.1 \%)$ & $8107(51.5 \%)$ & $<0.0001$ \\
\hline Never Smoker & $6819(40.9 \%)$ & $7635(48.5 \%)$ & \\
\hline Number $(\%)$ affected w/Lung cancer: & $724(3.8 \%)$ & $282(1.7 \%)$ & \\
\hline Median age at diagnosis & 60 & 61 & \\
\hline Mean age at diagnosis $( \pm$ SD) & $60.2 \pm 11.3$ & $60.0 \pm 11.3$ & 0.72 \\
\hline Missing age at diagnosis & $27(3.7 \%)$ & $11(3.9 \%)$ & 0.90 \\
\hline
\end{tabular}


Table 5

Odds ratios (95\% confidence interval) of risk of lung cancer among first-degree relatives of cases compared to first-degree relatives of controls among subjects included in the generalized estimating equations analysis

\begin{tabular}{|c|c|c|c|}
\hline & $\begin{array}{l}\text { \# affected } \\
\text { relatives with } \\
\text { lung cancer }\end{array}$ & $\begin{array}{l}\text { \# unaffected } \\
\text { relatives }\end{array}$ & $\begin{array}{c}\text { Lung Cancer Risk among First- } \\
\text { Degree Relatives } \\
\text { Adjusted OR }(95 \% \mathrm{CI})\end{array}$ \\
\hline Overall & 2233 & 57693 & $1.55(1.39,1.73)$ \\
\hline \multicolumn{4}{|l|}{ Proband Gender } \\
\hline Male & 969 & 26230 & $1.34(1.14,1.58)$ \\
\hline Female & 1264 & 31463 & $1.74(1.50,2.00)$ \\
\hline \multicolumn{4}{|l|}{ Proband Ethnicity } \\
\hline White & 2093 & 51842 & $1.53(1.37,1.71)$ \\
\hline Black/African American & 122 & 5306 & $2.09(1.28,3.42)$ \\
\hline \multicolumn{4}{|l|}{ Proband Histology } \\
\hline Small cell carcinoma & 88 & 1973 & $2.45(1.72,3.48)$ \\
\hline Non-small cell carcinoma & 1167 & 24738 & $2.46(2.02,2.98)$ \\
\hline \multicolumn{4}{|l|}{ Proband Smoking Status } \\
\hline Never Smokers & 393 & 14972 & $1.38(1.08,1.75)$ \\
\hline Ever Smokers & 1833 & 42634 & $1.57(1.42,1.74)$ \\
\hline Ex-Smokers & 989 & 20837 & $1.62(1.38,1.91)$ \\
\hline Current Smokers & 841 & 21670 & $1.61(1.34,1.93)$ \\
\hline \multicolumn{4}{|l|}{ Proband Age of Onset } \\
\hline$<50$ & 298 & 15184 & $1.97(1.51,2.58)$ \\
\hline $50+$ & 1935 & 42509 & $1.53(1.36,1.72)$ \\
\hline \multicolumn{4}{|l|}{ Relationship to Proband } \\
\hline Father & 816 & 11333 & $1.33(1.13,1.57)$ \\
\hline Mother & 411 & 11793 & $1.39(1.12,1.75)$ \\
\hline Siblings & 1006 & 34567 & $1.96(1.65,2.34)$ \\
\hline \multicolumn{4}{|l|}{ Relative Smoking Status } \\
\hline Never Smoker & 177 & 24091 & $1.31(0.96,1.78)$ \\
\hline Ever Smoker & 1750 & 28503 & $1.57(1.41,1.76)$ \\
\hline
\end{tabular}

ORs adjusted for: gender of proband, proband ethnicity, proband histology, proband smoking status, proband age of onset, relationship to proband, gender of relative, smoking status of relative (where appropriate). 